\title{
ДВУСТОРОННИЕ ОТНОШЕНИЯ
}

\author{
BILATERAL RELATIONS
}

\section{Admission of Turkey into the European Union: “Does Religion Matter?"}

\author{
Saroj K. Aryal ${ }^{1 \mathbb{D}} \bowtie$, Adithyan Nair ${ }^{1} \mathbb{D}$, Gaurav Bhattarai ${ }^{2}$ \\ ${ }^{1}$ University of Warsaw, Warsaw, Poland \\ ${ }^{2}$ Tribhuwan University, Kathmandu, Nepal \\ \sk.aryal@uw.edu.pl
}

\begin{abstract}
With the rising fear of Islamisation in Europe and increasing Islamist sentiment in Turkey, the issue of religion in the context of integration of Turkey into the European Union remains relevant. After a long-lasted wait and continuous negotiations, Turkey seems to be moving further away from getting accepted in the EU. The research focuses on the religious factor in this unrelenting friction between the two regions / entities and answers the question as to why the EU and Turkey should consider religion as one of the variables in the European integration. The analysis is done with the use of primary and secondary sources with special focus on Samuel Huntington's realism-inspired work 'Clash of the Civilization.' Turkish sources were used for better understanding the dynamics of Turkey. In terms of methodological approach the research is done with using the content analysis and contemporary observation of socio-political scenario and behavioral changes that the EU and Turkey going through. The authors conclude that there is no proper mechanism to consider religion as a variable, but psychologically it is still playing a major role in both the EU and Turkey. The authors believe that the EU and Turkey should discuss the religious dimension of integration while talking other dynamics.
\end{abstract}

Key words: European Union, Turkey, Religion, European Integration, Turkey in EU

For citation: Aryal, S. K., Nair, A., \& Bhattarai, G. (2021). Admission of Turkey into the European Union: "Does Religion Matter?”. Vestnik RUDN. International Relations, 21(3), 571-582. https://doi.org/10.22363/2313-06602021-21-3-571-582

(c) Aryal S.K., Nair A., Bhattarai G., 2021 


\title{
Вступление Турции в Европейский союз: «Имеет ли религия значение?»
}

\author{
С.К. Арьял ${ }^{1} \bowtie$, А. Наир ${ }^{1} \mathbb{Q}$, Г. Бхаттараи ${ }^{2}$ \\ ${ }^{1}$ Варшавский университет, Варшава, Польша \\ ${ }^{2}$ Университет Трибхуван, Катманду, Непал \\ \sk.aryal@uw.edu.pl
}

\begin{abstract}
Аннотация. На фоне растущего страха Европы перед исламизацией и обострения исламистских настроений в Турции религия по-прежнему представляет собой важнейший фактор в контексте интеграции Анкары в Европейский союз (ЕС). После длительного ожидания и непрерывных переговоров Турция все больше отдаляется от перспективы быть принятой в ряды ЕС. Выявляется роль религии в неослабевающих трениях между двумя регионами / субъектами и обосновывается тезис, что религию следует рассматривать в качестве одной из переменных европейской интеграции. Анализ опирается на первичные и вторичные источники с обращением к реалистско-ориентированному «Столкновению цивилизаций» Сэмюэля Хантингтона. Для лучшего понимания динамики политических процессов в Турции использовались турецкие источники. С точки зрения методологического подхода исследование проводилось посредством контент-анализа и наблюдения за социально-политическими сценариями и поведенческими изменениями ЕС и Турции. В заключении сделан вывод, что надлежащий механизм для рассмотрения религии в качестве переменной отсутствует. Вместе с тем религия по-прежнему играет важную психологическую роль как в ЕС, так и в Турции. Выдвинута рекомендация по проработке Брюсселем и Анкарой религиозного измерения интеграции в контексте общей интеграционной динамики.
\end{abstract}

Ключевые слова: Европейский союз, Турция, религия, европейская интеграция, Турция в ЕС

Для цитирования: Aryal S.K., Nair A., Bhattarai G. Admission of Turkey into the European Union: "Does Religion Matter?" // Вестник Российского университета дружбы народов. Серия: Международные отношения. 2021. Т. 21. № 3. С. 571-582. DOI: 10.22363/2313-0660-2021-21-3-571-582

\section{Introduction}

The aim of the research is to address religion as one of the variables in the TurkishEuropean Union integration. As there have already been wide discussions regarding the economic and political aspects, very few scholars actually addressed the religious impact of the integration on both parties. In case of the positive outcome Europe as a traditionally Christian region, admitting a Muslim dominated country, is going to do the first step towards religious tolerance at the institutional level.

Turkey was defined as a modern, secular, and western state by the late 20th century leaders who followed the Ataturk tradition. Turkey allied with the NATO which was headed by the West in the Gulf War. At the same time, however, elements in Turkish society have supported an Islamic revival, and scholars have argued that Turkey is basically a Middle Eastern Muslim society. Likewise, due to Turkey's mixed responses to global situations have made it a complex situation for scholars to classify the country into a particular civilization. Former
President Turgut Özal assumed that Turkey would never be a member of the European Union, emphasizing that "we are Muslim, and they are Christian, and they don't say that" (Huntington, 1993).

The Turkish quest for the EU admission began after the signature of a Customs Union Agreement 56 with the EU in 1995. Turkey was officially recognized as a candidate for full membership on December 12, 1999 at the Helsinki summit of the European Council (Kubicek, 2005). Negotiations for full membership started on October 3, 2005 (Font, 2006). It was a slow progression and only 16 out of 35 chapters that were necessary to comply with the accession had been opened and one had been closed by May 2016. The early 2016 refugee deal between Turkey and the European Union was supposed to pace up the negotiations after previous stagnation and allow visa-free travel through Europe for Turks. Since 2016 accession negotiations have stalled. The EU accused and criticized Turkey for rights violations and deficits in rule of law. On 26 June 
2018, the EU's General Affairs Council stated that "Turkey has been moving further away from the European Union"1.

While Europe criticized about the planned Turkish policies which potentially violate the Copenhagen Criteria of Eligibility, the European members of the Union are hesitant to look at the advantages of Turkish admission into the Union. Turkey can contribute to Europe in various ways. Turkish addition to the Union can address and resolve some of the issues that Europe has been facing. Turkish membership could increase the economic potential of the European Union and could make Europe more competitive on the global arena. Turkey is no longer "a sick man of Europe," it experiences rapid economic growth over the last years. Furthermore, labor emigration from Turkey could help EU recover from its ageing population which affects the labor market (Modebadze \& Mehmet, 2015). However, the EU's broadmindedness when it comes to religious tolerance is questionable. Although the European region may be known as the epicenter of liberalism and tolerance, the region has been facing a populist religious trend in politics (Foret, 2015).

From the late 19th century and onwards throughout the 20th century, several European states did not value the significance of the role of religion in international politics. As a result, when the EU institutions were established, they had no specific instruments for dealing with religious issues. "This changed when president of the European Commission Jacques Delors launched a dialogue with religious representatives. Religion also became part of the debate on the 'religious roots of Europe' during the negotiations on a Treaty establishing a Constitution for Europe, which was rejected in 2005. The Treaty of Lisbon ${ }^{2}$ institutionalized the

\footnotetext{
${ }^{1}$ Peter M. EU Council issues strong message about Turkey's obligations // Cyprus Mail. July 26, 2018. URL: https://cyprus-mail.com/2018/06/26/eu-council-issuesstrong-message-about-turkeys-obligations/ (accessed: 12.02.2021).

2 The Lisbon Treaty, also known as the Treaty of Lisbon, updated regulations for the European Union, establishing a more centralized leadership and foreign policy, a proper process for countries that wish to leave the
}

dialogue with representatives of confessional and philosophical organizations" 3 .

This research attempts to provide the answer to the question 'Why Islam is an important variable in Turkey's integration into the EU?' The central assumption is that church based identity politics in Europe has been strengthened and therefore religion plays a vital role for Turkey's acceptance into the European Union. Turkish-EU integration would symbolize Christianity's tolerance towards Islam and vice versa. In terms of theoretical framework the European-Turkish integration is analyzed from the perspective of classical realism and will be based on Samuel Huntington's "Clash of Civilizations." The paper begins with a theoretical and methodological framework, and then discusses the general overview of religion as a variable in interstate relations with special focus on the contemporary state of religious factor in the discourse between the EU and Turkey.

\section{Theoretical Approach: What's Behind the Clash of Civilizations?}

Classical realism with its special vision of human nature, power and interest is regarded as most suitable for sub-state account of religion. Accepting the pessimistic character of human nature the research proceeds from the assumption that the future wars would commence due to the religious differences among different civilizations.

Samuel Huntington predicts the shift away from Western power towards Asian and Islamic civilizations. The Islamic world has faced a recent religious resurgence in which modernization played an important role. As people migrate from their family structures into cities in search of industrial jobs, they often lose their old sense of identity. In the absence of strong family or community ties, religion

Union, and a streamlined process for enacting new policies.

${ }^{3}$ Perchoc P. Religion and EU's external policies // European Parliamentary Research Service. February 2020. URL: https://www.europarl.europa.eu/RegData/etudes/ IDAN/2020/646173/EPRS_IDA(2020)646173_EN.pdf (accessed: 16.02.2021). 
presents a good alternative for building a new identity. Huntington argues that the rise of Islam contributes to religious riots and religious political agendas. As a result the Muslim civilization becomes less stable. However, he acknowledges the influence of Islamic societies in international politics mostly due to their demographic growth and cultural confidence.

Huntington explains that the Western desire to exert its influence and dominate the world leads to conflict with Muslim countries and China, which gained in strength and refuses to succumb to Western dominance. Huntington (1993) states that moving forward the West will have to compromise on issues such as militarization, human rights, refugees and immigrants, which are traditionally conflict-prone.

Turkey being a Muslim dominated country with rising Muslim sentiment is susceptible to the potential Western religious and cultural dominance. According to Huntington (1996), Turkey is a 'torn' country, in the sense that its leaders typically wish to pursue a bandwagon strategy and make the country member of the West. But Turkish history, culture and traditions are far from being Western. Purely on an analytical note, considering the conflicts that have occurred in the past due to religion, the potential inclusion of Turkey into the European Union can mean that Huntington's theory is most likely to come into play.

\section{Role of Religion in Shaping Inter-State Relations}

Religion has consistently been rejected in international relations. Scott Thomas (2000) and Jeffrey Haynes (2007) provide some answers to the question how religion matters in the international sphere. By critically evaluating possible dimensions of religion relevant for International Relations (IR) (religion as ideology, identity, trans-national idea, actor, soft power, civilization or culture), Thomas argues that in order to avoid essentialism and account for change, religion is best intellectualized as interpretive communities. This point is methodologically important, but the possibility to analyze religion through multiple dimensions based on that premise is not excluded. Haynes's theory views religion as a soft power. Foreign policies can be influenced or motivated by religious groups. Both authors stress that "religion as transnational idea and competing vision of international society influences IR primarily by challenging the universality of IR norms (such as sovereignty, territorial integrity, non-intervention) and the very the foundation of the Westphalian system. However, they do not go far enough to show possible ways in which the relationship between religion as (changeable) belief / ideas and action / policies can methodologically be approached" (Sheikh, 2012).

Jonathan Fox points out three ways how religion influences international politics. First, it affects foreign policies through the individual beliefs of actors. Second, it gives legitimacy for support or criticism of government behavior. Third, it can transform local issues into international issues (Fox, 2001). In his book on ethno-religious conflicts, he proceeds to argue that religion qua its multiple functions appears to work in the same way as ethnic identification (Fox, 2002).

The world history is rich in examples of religious conflicts and wars. The biggest of this would be the Thirty Years War in Europe, a 17th-century religious conflict fought primarily in Central Europe. It remains one of the longest and most brutal wars in human history, with more than 8 million casualties resulting from military battles as well as from the famine and disease caused by the conflict. The war lasted from 1618 to 1648 , starting as a battle among the Catholic and Protestant states that formed the Holy Roman Empire ${ }^{4}$.

Another modern-day example of religious conflict would be India - Pakistan relations. Pakistan, an Islamic republic has been having border disputes and continuous diplomatic struggles with its neighbor India, who as declared in the Constitution of India, is a secular nation but meanwhile is witnessing a rising Hindu nationalistic government. The Kashmir conflict, a territorial conflict over the Kashmir

\footnotetext{
${ }^{4}$ The Thirty Years War // New Advent. URL: http://www.newadvent.org/cathen/14648b.htm (accessed: 16.02.2021).
} 
region was the main source of conflict, primarily between India and Pakistan, with China playing a third-party role. The conflict started after the partition of India in 1947, as both India and Pakistan claimed the entirety of the former princely state of Jammu and Kashmir ${ }^{5}$.

Although religious conflicts usually occur between two different religions, even communities with the same religious roots might have conflicts. A widely televised example of this situation would be the Shia and Sunni conflict. Although both communities have the same religious roots, today they have different religious practices, customs, and traditions. The 2011 Bahraini uprising showcased the ShiaSunni conflict. Although the Bahraini population mainly consists of Shia Muslims, the ruling family that governs Bahrain is Sunni. The Bahraini protests were initially aimed at achieving greater political freedom and equality for the majority Shia population, and expanded to a call to end the monarchy of Hamad Bin Isa Al Khalifa. This shows that religion should also be considered as a driving factor during the integration of two different communities of the same religion ${ }^{6}$.

\section{Rise of Islamophobia Post-9/11 War and after Trump Administration}

The relevancy of religion in contemporary politics was clearly demonstrated during the 4-years presidency of Donald Trump who used anti-Muslim sentiments as the main factor in his political campaign. According to the NBC study, issued in December 2015, $25 \%$ of Americans supported Trump's Muslim ban. In four months, Trump's Muslim ban gained more than 51\% support. This increase comes because of Trump's rising Islamophobic publicity and shows that he used the chance to use this wave to reach the climax in his political journey (Sunar, 2017).

\footnotetext{
${ }^{5}$ Dalrymple W. The great divide // The New Yorker June 22, 2015. URL: https://www.newyorker.com/ magazine/2015/06/29/the-great-divide-books-dalrymple (accessed: 13.02.2021).

${ }^{6}$ McEvers K. Bahrain: The Revolution that wasn't // NPR. January 5, 2012. URL: https://www.npr.org/2012/ 01/05/144637499/bahrain-the-revolution-that-wasnt (accessed: 13.02.2021).
}

The government initiated a political movement against American Muslims. "Trump supporters attacked, harassed, or plotted to kill Muslims during the election cycle, proving a potential link between Trump's rhetoric and the actions of supporters" $"$.

U.S having an influential soft power has also contributed to the rising (of) Islamophobia in Europe. Taking the example of Ander Breivik, a 32-year-old Norwegian that bombed a government building in Oslo killing 8 people and also shooting 68 people to death after the bombing in 2011. Breivik's manifesto contains numerous footnotes and in-text citations to American bloggers and pundits, quoting them as experts on Islam's "war against the West." This small group of anti-Muslim organizations and individuals in our nation is obscure to most Americans but wields great influence in shaping the national and international political debate. Their names are heralded within communities that are actively organizing against Islam and targeting Muslims in the United States ${ }^{8}$.

The above examples of the conflicts that occurred during the Early Modern period of Europe and in current time, the rise of Islamophobia in the United States and the influence it can have on other countries show that religion has been and still is a very influential factor in politics.

\section{Assessment of Negotiations between the $E U$ and Turkey}

Turkey has been trying to attain the EU membership since 1963, but it was not until the late 1990s, with the establishment of the Customs Union in 1996, that the EU gave some positive signals to Turkey that it could be a potential candidate. However, Turkey's expectations of fast-tracking the process of

\footnotetext{
${ }^{7}$ Mathias C. 6 Rules of Islamophobia in America // Huffington Post. January 23, 2017. URL: https://www.huffpost.com/entry/islamophobia-america_n 587cf491e4b0e58057ff98e 0 (accessed: 13.02.2021).

${ }^{8}$ Ali W., Clifton E., Duss M., Fang L., Keyes S., Shaker F. The Roots of the Islamophobia Network in America // The Center for American Progress. August 26, 2011. URL: https:/www.americanprogress.org/issues/ religion/reports/2011/08/26/10165/fear-inc/ (accessed: 13.02.2021).
} 
joining the EU were quickly and unexpectedly hindered. The 1997 Luxembourg European Council launching the enlargement process included the Central and Eastern European countries (CEEC), but excluded Turkey. The country felt it had been 'leapfrogged' by the post-communist applicants (Neuwahlm, 1999). Two years later the EU granted Turkey candidate status. At that point Turkey was excluded from opening accession negotiations, while 12 other candidates conducted accession talks or were invited to do so starting from 2000.

The negotiations surrounding the Helsinki summit were quite challenging for Turkey as some European countries, namely Greece and Sweden, expressed their objections towards the Turkish candidacy (Hale, 2000). However, this issue did not lead to insurmountable disagreements as very few in the EU trusted Turkey's capacity to improve its democratic credentials and even less perceived Turkey's future membership as being a real option. At that time, the EU commitment to Turkey merely seemed like a symbolic gesture. Not surprisingly, the 2000 Nice Treaty included the 12 candidates in the distribution of institutional power sharing, but left Turkey out.

The unanticipated consequences of the 1999 institutional arrangement became visible three years later. The formalization of Turkey's candidacy, while surrounded by scepticism within the EU on chances of meeting the membership requirements, it encouraged a selfreinforcing two-way process: on the applicant's side, it increased Turkey's incentives to progress in fulfilling the 1993 Copenhagen criteria9; on the EU side, it fostered political and financial cooperation with the candidate and took a step forward towards accession. In the light of the progress made by the candidate and the EU, in 2002, as the EU agenda included deciding on a date to start accession negotiations, Turkey's

\footnotetext{
${ }^{9}$ The Treaty on European Union sets out the conditions (Article 49) and principles (Article 6(1)) to which any country wishing to become an EU member must conform. Certain criteria must be met for admission. These criteria (known as the Copenhagen criteria) were established by the Copenhagen European Council in 1993 and strengthened by the Madrid European Council in 1995.
}

membership unexpectedly and for the first time appeared a plausible option for many of the European elite. The increasing confidence in Turkey's chances of improving its democratic performance in turn led to objections being raised by certain European partners and the issue of Turkey's accession became a highly sensitive topic on both the EU and national agendas. The EU concluded that accession talks with Turkey would be opened without delay if by December 2004 the candidate met the political criteria institutions guaranteeing democracy, the rule of law, human rights and respect for and protection of minorities, based on the recommendations from the Commission.

"Following the 2002 Council's resolution the controversy over Turkey's membership became even more intense: the issue of Turkey's accession divided public opinion, captured a lot of attention in European media and generated intense debate within EU institutions. However, even though Turkey's accession divided the European elite and public opinion, progress following the 2002 confirmation of EU commitment with the candidate nurtured the post-Helsinki institutional dynamics. Based on a long-awaited recommendation by the Commission, in December 2004 the European Council gave the green light to Turkey's accession by deciding to start negotiations in October 2005, despite the outcome not being guaranteed beforehand" (Font, 2006). This showed the world that Europe was not religiously intolerant and was a huge step towards portraying the world as a liberal region that it is known for now.

The Helsinki agreement initiated a different institutional course of action and generated new institutional dynamics with a series of selfreinforcing effects. First, it created new expectations and incentives on the applicant's side to make progress in fulfilling the Copenhagen conditions. Turkey adopted farreaching constitutional, legislative and policy reforms in order to meet the political criteria. Second, a more proactive and cooperative strategy was in action rather than the EU's traditional containment strategy. In particular, an Accession Partnership was offered by the EU 
which was built on enhanced political dialogue and financial assistance. Third, opinions were changing amongst the member states and Turkey's accession was viewed as a plausible option in the long run. Fourth, it reduced the range of possible EU options to those having a treaty-based legitimacy and framed them within the post-Helsinki institutional dynamic. This means that the EU abandoned the idea of elevating a Christian culture to the status of membership and rejected the possibility of giving the candidate a 'privileged partnership' instead of the prospect of membership ${ }^{10}$.

\section{Religion in the EU and Turkey}

\section{Spread of Fear of Islamisation in Europe}

Islamisation is the process of bringing someone or something under the influence of Islam or Islamic rule. Ever since the increased immigration of workers from countries like Turkey, Pakistan, India and Central Asian, the fear of Islamisation in Europe has drastically increased. There have been several incidents of terrorism between the two religions in Europe ${ }^{11}$.

The Charlie Hebdo incident in Paris was one of the most widely covered stories by the media (such as the Guardian and BBC). In 2012 Charlie Hebdo, famous for its satirical attacks on political and religious leaders, published cartoons of the Islamic Prophet Mohammed, forcing France to temporarily close embassies and schools in more than 20 countries amid fears of reprisals. On 7 January 2015, brothers Chérif and Saïd Kouachi stormed the Paris offices of Charlie Hebdo in the Rue Nicolas-Appert before opening fire on its staff and murdering 11 people including five of the satirical magazine's cartoonists. A police officer was murdered outside the building. The Kouachis were killed in

${ }^{10}$ Mirel P. European Union-Turkey: from an illusory membership to a "Privileged Partnership" // Foundation Robert Schuman. June 16, 2017. URL: https://www.robertschuman.eu/en/european-issues/0437-european-unionturkey-from-an-illusory-membership-to-a-privilegedpartnership (accessed: 13.02.2021).

${ }^{11}$ Research Findings // European Union Agency for Fundamental Rights. URL: https://ra.europa.eu/en/ databases/anti-muslim-hatred/research-findings?page $=3$ (accessed: 13.02.2021). a shootout with police two days later ${ }^{12}$. Turkish reaction to the incident was mixed. R.T. Erdoğan announced his condolences and said that no religion supports terrorism and that this act of terrorism should not be associated with the Muslim religion. Ali Sahin, a Turkish official said that the attack was staged like in a movie ${ }^{13}$.

Franco-Turkish tensions have further increased due to France's accusations against Turkey about sending Syrian Jihadists to Nagorno-Karabakh conflict. Turkey supports Muslim nation Azerbaijan whereas France has shown its support to Armenia. On his arrival at the EU summit in Brussels Macron declared, "We now have information which indicates that Syrian fighters from jihadist groups have (transited) through Gaziantep (south-eastern Turkey) to reach the Nagorno-Karabakh theatre of operations. It is a very serious new fact, which changes the situation"14.

Another reason for the upsurge of Islamophobia in Europe is because of the rise of right-wing politicians in Europe with their agendas focused on Islamophobia and used as a political leverage. As Europe was experiencing a downfall in public welfare due to the economic crisis, extreme-right parties developed a perception which viewed immigrants as not primary citizens of their countries, and adopted discourses blaming immigrants and especially Muslims as a burden on their national economy. Although it is wrong to approach all extremeright parties in Europe like they are identical organizations, these have certain common characteristics. By their nature they are inclined to be authoritarian, radical, populist, nationalist and racist as well as having sceptical approaches

${ }^{12}$ Charlie Hebdo: Fourteen guilty in 2015 Paris terror attacks trial // BBC. December 16, 2020. URL: https://www.bbc.com/news/world-europe-55336094 (accessed: 13.02.2021).

${ }^{13}$ Idiz S. Mixed Turkish reaction to Paris massacre // Al-MONITOR. January 11, 2015. URL: https:/www.almonitor.com/originals/2015/01/turkey-france-parisattacks-turkish-reactions.html (accessed: 13.02.2021).

${ }^{14}$ Irish J., Rose M. France accuses Turkey of sending Syrian jihadists to Nagorno-Karabakh // Reuters. October 1, 2020. URL: https://www.reuters.com/article/us-armeniaazerbaijan-putin-macron-idUSKBN26L3SB (accessed: 13.02.2021). 
towards globalization and European integration (Kedikli \& Akça, 2018).

There have been several agendas and actions taken by political parties in European countries that showcase the intolerance of Europe towards Islam. For instance, France which is the home of more than five million Muslims has banned the use of veil in the public spaces in 2011 (Lucas, 2011). In Austria, Islamophobia is frequently exploited by populist parties such as Austria Freedom Party (Freiheitliche Partei Österreichs FPÖ) which was founded in 1956. It utilized the concept of Islamophobia in the parliament elections in 1999 for the first time. Their Islamophobia based election campaign was launched in 1999 and continued in their Vienna election campaigns in 2005 (Sezgin, 2019). They added a new dimension to it by using the billboards full of mottos such as "Pummer's Bell instead of Muezzin,", "Vienna First! Instead of Turkey in the EU." Furthermore, it was emphasized that immigration of Muslims needs to be opposed because they represent a threat to Europe.

Norway, a country that is deemed as tolerant, also witnessed a hate crime against Muslims by Anders Behring Breivik which resulted in the deaths of seventy-seven innocent people. Breivik stated that he was against multiculturalism and foreigners, and that Islam is a dangerous religion (Bangstad, 2014).

In Sweden, members of a far-right group (Stram Kurs) burned a copy of the Quran and this act was publicized by posting a video of it on social media, Rasmus Paludan being the main initiator and leader of the party ${ }^{15}$.

The hate speech has escalated into such a level that there have been groups formed that act as a catalyst to increase the spread of Islamophobia. SIOE (Stop Islamisation of Europe) is one of those groups that went global. It is a political interest group which has been active in Denmark. It arranges protests and mainly communicates using the website ${ }^{16}$. The

\footnotetext{
${ }^{15}$ Sweden: Far-right activists burn copy of Quran, plan more stunts // Al Jazeera. September 10, 2020. URL: https://www.aljazeera.com/news/2020/9/10/sweden-farright-activists-burn-copy-of-quran-plan-more-stunts (accessed: 15.02.2021)

${ }^{16}$ Stop Islamisation of Europe (SIOE), also known as Stop the Islamification of Europe, is a group with the
}

group says that its aim is to oppose Islamic extremism; it has the motto "Racism is the lowest form of human stupidity, but Islamophobia is the height of common sense." A branch of SIOE has also been set up in Poland in 2007.

While Islamophobia continues in Europe, it is worth mentioning that Europe has taken some key steps to ensure the safety of the Muslim community and to stop these hate speeches and crimes. The Charter of Fundamental Rights could be considered as the beginning of actions of the EU against racism and Islamophobia. This charter gained status of joint declaration of three bodies after it was executed by the chairman of the Council and Commission on April 5, $1977^{17}$. The "International Convention on the Elimination of All Forms of Racial Discrimination" was signed on April 1, $1969^{18}$. This agreement forbids all sorts of racial, ethnical, national discrimination, exclusion, and privilege. Although 178 countries have signed this agreement, there are several signatory countries of this treaty that have showed examples of racism, islamophobia, hate crimes and hate speeches like Germany, Hungary, Austria, and Norway.

\section{Increase of Muslim Sentiment in Turkey}

Although Turkey has shown signs of westernization, the Justice and Development Party (AKP), Turkey's democratically elected ruling party since 2002, brings to the philosophical debate on Islamist parties and

stated goal of "preventing Islam from becoming a dominant political force in Europe." It is a political interest group which has been active in Denmark and has conducted anti-Islamic protests in the United Kingdom. The group originated out of the joining of the Danish group Stop Islamisation of Denmark with English antiIslam activists. The group says that its aim is to oppose Islamic extremism; they have the motto "Racism is the lowest form of human stupidity, but Islamophobia is the height of common sense."

17 The Charter of Fundamental Rights // European Parliament. URL: https://www.europarl.europa.eu/ RegData/etudes/fiches techniques/2013/010106/04A_FT (2013)010106_EN.pdf (accessed: 15.02.2021).

${ }^{18}$ International Convention on the Elimination of All Forms of Racial Discrimination // United Nations Human Rights Office of the High Commissioner. January 4, 1969. URL: https://www.ohchr.org/en/professionalinterest/pages/ cerd.aspx (accessed: 16.02.2021). 
democracy. Unlike the Virtue Party and Welfare Party, the AKP broke from its traditional Islamist predecessors under the leadership of Recep Tayyip Erdoğan, refrained from making references to religion and termed itself as conservative democrat party (Çavdar, 2006). Some scholars and politicians say that the conservative perspective of politics that AKP maintains is quite like Christian Democratic parties in Western Europe (Turunc, 2007). All in all, the AKP appears less as an Islamist party and more as one that is pro-Western, pro-Market, and populist.

Even though AKP is trying to provide a proWestern and pro-market image internationally, AKP in Turkey has Islamist origins. It was established by the reformist wing of the MGH (Milli Görüş Hareketi) ${ }^{19}$ in 2001. The leaders of the party claimed to have abandoned the regressive Islamist outlook for democracy and human rights. Immediately after seizing power in 2002, AKP started democratization reforms aimed at fulfilling the Copenhagen criteria of the EU for strengthening democracy in Turkey (Yilmaz \& Bashirov, 2018). This led some scholars to argue that the party 'embraced a process of moderation and pragmatic change' over ideological objectives, and hence gave us 'the best picture we have so far of what Muslim Democracy might become and what it might stand for' (Nasr, 2005). Scholars argued that AKP pragmatically embraced notions of democracy to survive in power, reframe its image as a democratic actor, and gain the support of the EU and those segments of society that previously did not vote for Islamist parties, such as Kurds, liberals and the Gülen movement (Dagi, 2008).

In Turkey, political agendas are not religious in any sense. Rather the political regime has increasingly turned into a radical Muslim one and currently carries some of the most important features of such a regime. The change of the political regimes can be witnessed by the change

\footnotetext{
${ }^{19}$ Millî Görüş is a religio-political movement and a series of Islamist parties inspired by Necmettin Erbakan. It has been called one of "the leading Turkish diaspora organizations in Europe" and described as the largest Islamic organization operating in the West.
}

in the Turkish educational system. Due to AKP's political regimes the education centers and schools now promote its Islamist ideology and 'capture the minds' in Turkey (Kandiyoti \& Emanet, 2017). The national education curriculum was emptied of philosophy, secular principles, and Darwin, and filled with religion and history courses that glorify jihad and martyrdom. AKP's Islamism demonstrated itself in the party's foreign policy as well. Particularly since the failed coup attempt in 2016, the AKP government grew increasingly anti-Western in its outlook. It went so far as accusing the US and EU of being behind the failed coup of 15 July 2017 (Yilmaz, 2014). Erdoğan brought back religion-civilizational animosity against the West in his rhetoric. Today, Erdoğan and his media constantly propagate the existence of a holy warfare between the Muslims and the Christian West and claim that the latter is bent on the former's destruction ${ }^{20}$.

Finally, a growing trend in AKP's Turkey has been the rising status of regime-connected religious scholars such as the head of Diyanet Mehmet Görmez and columnist / scholar Hayrettin Karaman, who have become instrumental in legitimizing the regime's policies through various Islamic injunctions like fatwas and declarations. Görmez made statements in support of the AKP government's newly emerging radical Islamist rhetoric attacking abortion, women's rights, and the New Year's celebrations [Öztürk 2016]. Furthermore, both Görmez and Karaman utilised a jihadist takfiri rhetoric to demonize the regime's opponents such as the Kurdish nationalists and the Gülenists and labelled them as 'out of Islam' and 'heretics.' This shows that the level of Islamic extremism is gradually increasing amongst the Turkish scholars.

\section{Religion and Turkey's Admission to EU}

For many, Turkey is a state with a rather religious Muslim population that threatens the

\footnotetext{
${ }^{20}$ Le Miere J. Muslims and Christians at War in Europe, Turkey Warns, Lamenting 'Clash between the Cross and the Crescent' // Newsweek. March 17, 2017. URL: http:/www.newsweek.com/erdogan-islam-christianitybattle-europe-569792 (accessed: 16.02.2021).
} 
Western arrangement of religion and politics. This is not due to its Western inspired Kemalist 'separation' of religion and the state at the institutional level (which in practice amounts to state control and subjugation of, rather than state separation from religion (Fox, 2008, pp. 246247; Jung \& Rauvere, 2008), but because of it being a Muslim country. It is argued that Turkey lacks Western-style secularism (Hurd, 2006) and some fear an 'Islamization of Europe' through Turkish accession (Tibi, 2006).

Furthermore, Turkey would be the first country with a predominantly Muslim population to join the Christian dominated EU and it is known that the matter of religion has a long history in the EU integration. Observers argue that Christian and mostly Catholic politicians initiated European integration (Kaiser, 2007; Madeley, 2010), and some observers claim that the integration 'was an act of the political imagination of Christian democracy' (Thomas, 2005 , p. 167). While drafting the EU Constitutional Treaty, the debate to add a reference about god was proof that Christian roots were present in the EU (Waschinski, 2007).

Additionally, various EU member states have subtly indicated that they are not in favor of Turkish accession due to the difference in religious identity. Belgium, for example, was initially in favor of Turkish membership but recently its stance has shifted when Prime Minister Charles Michel requested an end to these negotiations of accession. He pointed out Erdoğan's departure from European values and stressed that diplomatic relations were deteriorating swiftly under the autocratic president which indicates Erdoğan's rigid behavior regarding religious freedom of expression $^{21}$. France has been consistently against this accession, although recently there has been no discussion from President Macron's side. Europe is portrayed as a region with an exclusive identity rooted in history, culture and religion (Union for a Popular Movement) by members (Aydin-Düzgit, 2009). "To act

\footnotetext{
${ }^{21}$ Schuster K. Turkey - EU relations: Which countries are for and against Turkish accession? // DW News. September 6, 2017. URL: https://www.dw.com/en/turkeyeu-relations-which-countries-are-for-or-against-turkishaccession/a-40381533 (accessed: 16.02.2021).
}

together, in the fields of sovereignty, one has to be equipped with democratic institutions! Because this is the second aspect of the community or federal approach. Where there is power, there also must be democracy... And for democracy to be able to function the European citizens must have sufficient common points of references, they must share a vision of the world and of man. There is no political unity without a cultural unity!" (Aydin-Düzgit, 2009). In the quotation above, extracted from a speech where the UDF leader Bayrou lists his objections to Turkey's accession to the EU, representative democracy in the nation-state model is projected onto Europe, requiring culturally unified European citizens.

Finally, the Turkish membership debate is predominantly framed in terms of threat to the EU economy, culture and security of EU citizens (de Vreese et al., 2011). The cultural threat and the clash of civilization frames suggest religion playing an important but also controversial role in the mass mediated accession debate.

\section{Conclusion}

The European Union has no religious prerequisite that stops Turkey from being a part of the EU which already establishes that EU is a tolerant union. Although the EU has taken various countermeasures against islamophobia as stated above, its effectiveness is questionable. Turkish admission into EU can benefit the region both economically and is also advantageous to acquire the status of the most tolerant region in the world.

Turkish admission can also have a positive impact on the EU and help the region to combat with its demographic and labor shortage problems. But this is only possible if Turkish immigrants are viewed as an asset and not as a threat.

Religion comes into play when addressing this accession due to some countries that wish to keep the EU as a club of Christian nations. For the EU to move forward from its inward looking, imbalanced, and disproportionate focus on the older partners, embracing Turkey would alter the political and cultural outlook of the entire bloc. With the rising disputes in the region regarding religion, this status booster can prove to be 
crucial for the region in order to be example for other countries.

This accession can also be a striking example for the democratization of the Muslim world. Turkey could become a successful example of democratization for other Muslim states. Turkey could prove that Islamic values are compatible with liberal democratic values. The number of Muslim democracies could increase considerably if Turkey becomes the member of the European Union and joins the club of liberal democratic countries.

Turkey will have ample number of opportunities to increase their pace of development after the accession into the EU. This accession will help Turkey in fighting corruption, maintaining macroeconomic stability, free movement of labor which will allow Turkey to transfer the surplus labor force to Europe etc.

According to the research conducted above, it can be concluded that religion can act as a variable from the perspective of classical realism. As political agendas are being derived worldwide from religious roots (for example, Islamic law from Quran and Church politics), the countries are facing a surge of religious politics and this enhances the relevancy of religion when it comes to relation between states. In the EU, due to the absence of formal voting system, the member states must reach general agreement. This is usually the most used decision-making process within the EU council. So, it is extremely important for the EU to minutely observe the domestic political escalation in some of the member states regarding religious non-toleration.

Furthermore, the inclusion of Turkey in into EU would improve Muslim - Christian, East West relations with a single move, one that could have significant ramifications for the entire world. The unique political, social, and cultural character of Turkey, inherited from its transformation from an Islamic caliphate into a republic, means that the symbolism associated with Turkey's entry into the EU would have far greater effect in the long-term.

Received / Поступила в редакцию: 21.03.2021

Accepted / Принята к публикации: 10.06.2021

\section{References / Библиографический список}

Aydin-Düzgit, S. (2009). Constructing Europe through Turkey: French perceptions on Turkey's accession to the European Union. Politique Européenne, 3(29), 47-82. https://doi.org/10.3917/poeu.029.0047

Bangstad, S. (2014). Anders Breivik and the rise of Islamophobia. London: Zed books.

Çavdar, G. (2006). Islamist "New Thinking" in Turkey: A model for political learning? Political Science Quarterly, $121(3), 477-497$.

Dagi, I. (2008). Islamist parties and democracy: Turkey's AKP in power. Journal of Democracy, 19(3), 25-30. https://doi.org/10.1353/jod.0.0015

De Vreese, C. H., Boomgaarden, H. G., \& Semetko, H. A. (2011). (In)direct framing effects: The effects of news media framing on public support for Turkish membership in the European Union. Communication Research, 38(2), 179-205. https://doi.org/10.1177/0093650210384934

Font, N. (2006). Why the European Union gave Turkey the green light. Journal of Contemporary European Studies, 14(2), 197-212. https://doi.org/10.1080/14782800600892259

Foret, F. (2015). Religion and politics in the European Union: The secular canopy. Cambridge: Cambridge University Press.

Fox, J. (2001). Religion as an overlooked element of International Relations. International Studies Review, 3(3), $53-73$

Fox, J. (2002). Ethnoreligious conflict in the late twentieth century. Lanham: Lexington Books.

Fox, J. (2008). State religious exclusivity and human rights. Political Studies, 56(4), 928-948. https://doi.org/ $10.1111 / \mathrm{j} .1467-9248.2008 .00724 . x$

Hale, W. (2000). Turkish foreign policy, 1774-2000. Cambridge: Cambridge University Press.

Haynes, J. (2007). An introduction to International Relations and religions. 1st edition. Harlow: Pearson Education.

Huntington, S. P. (1993). The clash of civilizations? Foreign Affairs, 72(3), 22-49. https://doi.org/10.2307/ 20045621

Huntington, S. P. (1996). Clash of the civilizations and the remaking of world order. New York: Simon \& Schuster.

Hurd, E.S. (2006). Negotiating Europe: The politics of religion and the prospects for Turkish accession. Review of International Studies, 32(3), 401—418. https://doi.org/10.1017/S026021050600708X 
Jung, D., \& Rauvere, C. (2008). Religion, politics and Turkey's EU accession. London: Palgrave Macmillan.

Kaiser, W. (2007). Christian democracy and the origins of European Union. Cambridge: Cambridge University Press.

Kandiyoti, D., \& Emanet, Z. (2017). Education as a battleground: The capture of minds in Turkey. Globalizations, 14(6), 869-876. https://doi.org/10.1080/14747731.2017.1325170

Kedikli, U., \& Akça, M. (2018). Rising Islamophobic discourses in Europe and fight against Islamophobia on the basis of international organizations. Mediterranean Journal of Social Sciences, 9(1), 9-23. https://doi.org/ $10.2478 / \mathrm{mjss}-2018-0001$

Kubicek, P. (2005). Turkish accession to the European Union: Challenges and opportunities. World Affairs, 168(2), $67-78$.

Lucas, M. H. (2011). Understanding the French ban on the veil. Economic and Political Weekly, 46(18), 25-27.

Madeley, J. (2010) E Unum Pluribus: The role of religion in the project of European integration. In J. Haynes (Ed.), Religion and politics in Europe, the Middle East and North Africa (pp. 114-135). London: Routledge.

Modebadze, V., \& Mehmet, F. (2015). Why Turkey should join the European Union: Arguments in favor of Turkish membership. Journal of Liberty and International Affairs, 1(2), 1-9.

Nasr, S. V. R. (2005). The rise of "Muslim democracy". Journal of Democracy, 16(2), 13-27. https://doi.org/ 10.1353/jod.2005.0032

Neuwahlm, N. (1999). The EU — Turkey Customs Union: A balance, but no equilibrium. European Foreign Affairs Review, 4(1), 37-62.

Öztürk, A. E. (2016). Turkey's Diyanet under AKP rule: From protector to imposer of state ideology? Journal of Southeast European and Black Sea Studies, 16(4), 619 - 635. https://doi.org/10.1080/14683857.2016.1233663

Sezgin, Z. (2019). Islam and Muslim minorities in Austria: historical context and current challenges of integration. International Migration \& Integration, 20, 869-886. https://doi.org/10.1007/s12134-018-0636-3

Sheikh, M. (2012). How does religion matter? Pathways to religion in International Relations. Review of International Studies, 38(2), 365-392.

Sunar, L. (2017). The long history of Islam as a collective "Other" of the West and the rise of Islamophobia in the U.S. after Trump. Insight Turkey, 19(3), 35—52. https://doi.org/10.25253/99.2017193.03

Thomas, S. (2000). Religion and international conflict. In K. Dark (Ed.), Religion and International Relations (pp. 1-23). London: Macmillan.

Thomas, S. (2005). The global resurgence of religion and the transformation of International Relations. The struggle for the soul of the twenty-first century. New York: Palgrave Macmillan.

Tibi, B. (2006). Europeanizing Islam or the Islamization of Europe: Political democracy vs. cultural difference. In T. A. Byrnes \& P. J. Katzenstein (Eds.), Religion in an expanding Europe (pp. 204-224). Cambridge: Cambridge University Press. https://doi.org/10.1017/CBO9780511491917.009

Turunc, H. (2007). Islamicist or democratic? The AKP's search for identity in Turkish politics. Journal of Contemporary European Studies, 15(1), 79-91. https://doi.org/10.1080/14782800701273417

Waschinski, G. (2007). Gott in die Verfassung?: Religion und Kompatibilität in der Europäischen Union. BadenBaden: Nomos.

Yilmaz, I. (2014). Religious freedom, the Muslim identity and the secularist social-engineering project in Turkey. Quaderni di Diritto e Politica Ecclesiastica, (1), 197-204.

Yilmaz, I., \& Bashirov, G. (2018). The AKP after 15 years: Emergence of Erdoganism in Turkey. Third World Quarterly, 39(9), 1812-1830. https://doi.org/10.1080/01436597.2018.1447371

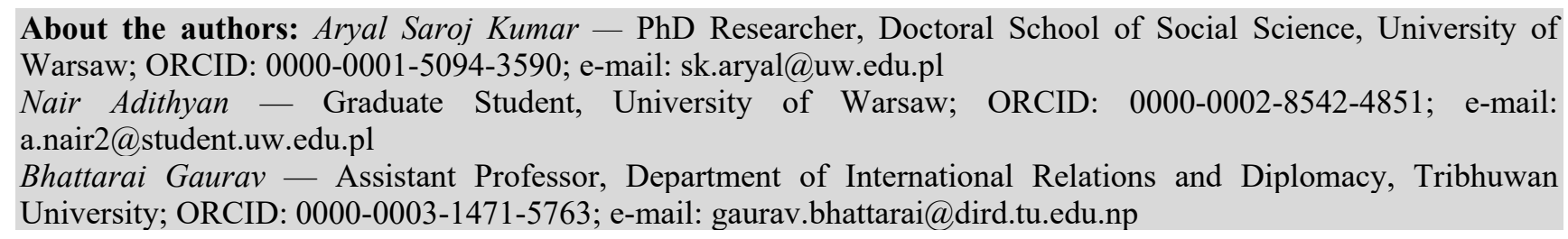

Сведения об авторах: Арьял Сародж Кумар - аспирант Школы социальных наук Варшавского университета; ORCID: 0000-0001-5094-3590; e-mail: sk.aryal@uw.edu.pl

Наир Адитьян - магистрант Варшавского университета; ORCID: 0000-0002-8542-4851; e-mail: a.nair2@student.uw.edu.pl.

Бхаттараи Гаурав - доцент кафедры международных отношений и дипломатии Университета Трибхуван; ORCID: 0000-0003-1471-5763; e-mail: gaurav.bhattarai@dird.tu.edu.np 